\title{
Scots pine (Pinus sylvestris L.) site index in relation to physico-chemical and biological properties in reclaimed mine soils
}

\author{
Marcin Pietrzykowski $\cdot$ Jarosław Socha $\cdot$ Natalie S. van Doorn
}

Received: 15 January 2014/ Accepted: 3 October 2014/Published online: 18 October 2014

(C) The Author(s) 2014. This article is published with open access at Springerlink.com

\begin{abstract}
The aim of this work was to assess Scots pine (Pinus sylvestris L.) growth response and potential productivity on various reclaimed mine soils (RMS) developed on dominant parent rock in Poland (Central Europe). The study was conducted on four afforested post-mining sites after lignite, hard coal, sand and sulphur mining extraction. Site index (SI) was modeled as a function of the top height of a pine tree stand at a certain age and physico-chemical and biological properties of RMS. Field measurements were taken in tree stands ranging from 12 to 30 years of age. A total of 42 site trees (1-2 dominant trees on each plot) representing top height $\left(\mathrm{H}_{500}\right)$ were cut and the age and height increment of each tree was estimated on the basis of distance between branch verticils. Soil samples were collected at $0-8,8-50$ and $50-110 \mathrm{~cm}$ depth and the following parameters were determined: soil texture, $\mathrm{pH}$, total exchangeable bases TEB, cations exchangeable capacity, soil organic carbon (SOC), nutrient content ( $, \mathrm{Ca}, \mathrm{Mg}, \mathrm{K}, \mathrm{Na}, \mathrm{P}$ ) and microbial properties (dehydrogenase activity; DHG). Statistical models were developed describing relationships between tree growth as expressed by SI and key mine soil properties. The best model explained a relatively large part $(>60 \%)$ of SI variability. In this model, the most influential RMS properties were: clay sized $(<0.002 \mathrm{~mm})$ fraction content, base saturation (BS\%), available phosphorus $\left(\mathrm{P}_{\mathrm{av}}\right)$ and biological activity (DHG). However, in acidic and sulphurised tertiary sands neutralized by bog lime, the correlation between SI and phosphorus was negative. This phenomenon can be explained in part by the possible disturbance of nutrient relationships in RMS. Developed models may be used to predict site
\end{abstract}

M. Pietrzykowski ( $\square)$

Department of Forest Ecology and Reclamation, Faculty of Forestry, University of Agriculture in Krakow, Al. 29 Listopada 46, 31-425 Kraków, Poland

e-mail: rlpietrz@cyf-kr.edu.pl

J. Socha

Department of Biometry and Forest Productivity, Faculty of Forestry, University of Agriculture in Krakow, Al. 29 Listopada 46, 31-425 Kraków, Poland

N. S. van Doorn

Department of Environmental Science, Policy and Management, University of California, 130 Mulford Hall, Berkeley, CA 94720, USA 
potential productivity and pine tree growth on newly reclaimed areas, or to plan forest management strategies and transformation of existing pine monocultures to mixed hardwood forests developed on mining sites similar to those analysed in presented research.

Keywords Mine soils - Afforestation - Scots pine - Tree growth response - Site index · Site productivity

\section{Introduction}

The rehabilitation of post-mine lands requires site-specific knowledge to ensure that the chosen reclamation strategies will be sustainable (e.g. Bradshaw 1983; Pietrzykowski and Krzaklewski 2007; Zipper et al. 2011a, b). A large part of post-mining areas in Europe (Knoche 2005; Pietrzykowski and Socha 2011) and in the eastern United States (Zipper et al. 2011b; Franklin et al. 2012) have been reclaimed to forest. In Poland (Central Europe) the area taken up by industry and mining is estimated at around 45,000 ha, circa 25,000 ha of which has been reclaimed to forestry.

Information about site productivity and tree species growth response is necessary for afforestation and forest management strategies on post-mine sites (Torbert and Burger 2000; Zipper et al. 2011a). The most commonly used and widely accepted method in forestry for assessing potential site productivity and species growth reaction is the site index (SI) which is determined by the use of site index models on the basis of the height of a stand at a certain age (e.g. Nord-Larsen et al. 2009). However, this approach is restricted to even-aged monocultures (Skovsgaard and Vanclay 2008; Sharma et al. 2012). In addition, the site index approach fails if dominant trees are not present, if stands are mixed species or uneven-aged, or if the area is unstocked, stocked with a different species than the one that should be predicted, or stocked with young stands where small errors in age or dominant height cause large errors in site index predictions (Sharma et al. 2002). An alternative way to estimate site index is to predict it from site variables describing climate, relief or edaphic properties (Hägglund and Lundmark 1977; Socha 2008; Bošela et al. 2011). This frequently used approach is classified as a "geocentric" (site-based) method (Skovsgaard and Vanclay 2008) and the models developed as a tool for site index prediction are called "site index prediction models"' (Sharma et al. 2012). Growth trajectories of site index models may be dependent on soil properties (Johansson 1995), however postmine soil properties significantly differ from natural forest soils and there is high spatial variability even on the same soil-substrate (parent rock) (Heinsdorf 1996; Torbert and Burger 2000; Pietrzykowski et al. 2013). Thus since soil conditions, among many other factors, play a role in determining growth patterns, the application of SI models developed for natural conditions to post-mine site conditions must be taken with extreme caution. Post-mining soil characteristics and specific local growing conditions (climate and relief of post-mine sites) may in fact cause significant differences in the growth patterns of forests, especially in the early stages of their development (Johansson 1995; Torbert and Burger 2000; Ochał et al. 2010). The use of inappropriate models may cause under- or overestimation of the site index depending on the age of the stand (Socha 2008; Nord-Larsen et al. 2009). An additional factor is that during mine reclamation, there is no past history for that site to use as a basis for site index and the use of soil properties and site characteristics for potential productivity and afforestation planning is necessary. 
Scots pine (Pinus sylvestris L.) is one of the most important species used for reclaiming mined lands in central Europe (Kuznetsova et al. 2010; Pietrzykowski 2014). It is native to Europe and Asia and has a common range extending west to Great Britain and Portugal, east to eastern Siberia, south to the Caucasus Mountains, and as far north as the Arctic Circle in Scandinavia (Farjon 2005). The response of Scots pine to mining site conditions requires further investigation (Baumann et al. 2006; Pietrzykowski 2010; Pietrzykowski et al. 2013). In particular, little is known about the influence of different mine soil properties on tree growth response and the resulting potential site productivity.

As a result, new local site index models should be developed for Scots pine on post reclaimed areas. The development of local SI models requires a large empirical data collection effort, which is not always feasible. However if that challenge can be overcome, the construction of local SI models is a better solution for predicting productivity on these sites.

The aim of this work is to analyse the influence of different mine soil properties on the growth response and potential productivity of Scots pine on different types of afforested post-mine areas. Specifically, this study develops site index prediction models, which describe the key properties of soils developed on different parent rock substrates at post mine sites after coal, lignite, sand and open strip sulphur mining extraction in this part of central Europe. Developed site index models can be used to (1) estimate site potential and pine tree growth and their usefulness in the afforestation on newly reclaimed areas and (2) select appropriate forest management strategies on mine sites and plan for the transformation of pine monocultures to mixed hardwood stands.

\section{Materials and methods}

The field studies were conducted in Scots pine stands on sites reclaimed to forestry in central and southern Poland (Fig. 1). Each site was situated on a different parent rock substrate. The sites were located on: (1) the hilltop of an external waste heap of Lignite Mine Belchatow $\left(\mathrm{BEL} ; 1^{\circ} 25^{\prime} \mathrm{E} ; 51^{\circ} 13^{\prime} \mathrm{N}\right)$; (2) a spoil heap of the hard coal mine Smolnica $\left(\mathrm{SMOL} ; 18^{\circ} 31^{\prime} \mathrm{E} ; 50^{\circ} 15^{\prime} \mathrm{N}\right) ; 3$ ) a sand mine cast Szczakowa $\left(\mathrm{SZCZ} ; 19^{\circ} 25^{\prime} \mathrm{E} ; 50^{\circ} 14^{\prime} \mathrm{N}\right)$; and 4) a waste heap of open-cast sulphur mine Piaseczno (PIAS; $21^{\circ} 34^{\prime} \mathrm{E} ; 50^{\circ} 33^{\prime} \mathrm{N}$ ) (Fig. 1). Characteristics of the sampled sites, reclamation treatments and parent rock substrates on study sites are given in Table 1.

\section{Field studies}

\section{Stand and tree measurement}

Field data were collected from 28 permanent plots (randomly oriented fixed squares of $10 \times 10 \mathrm{~m}$ in four replicates for seven substrate variants, Table 1) used as part of an ecosystem monitoring program of mining sites in Poland (Pietrzykowski and Socha 2011; Pietrzykowski 2014). Study plots were established in even-aged 12-30 year old Scots pine stands. Diameter at breast height $(\mathrm{DBH})$ and tree height $(\mathrm{H})$ were measured in the sample plots and basic tree stand characteristics were measured (Table 3). Next, a total of 42 site trees representing top height $\left(\mathrm{H}_{500}\right)$ were selected and cut for height growth analysis. Site trees without observable damage were selected on different parent rock/substrate variants. Mean diameter of site trees was $14.9 \mathrm{~cm}$ and varied from 6.5 and $28.8 \mathrm{~cm}$, whereas mean 


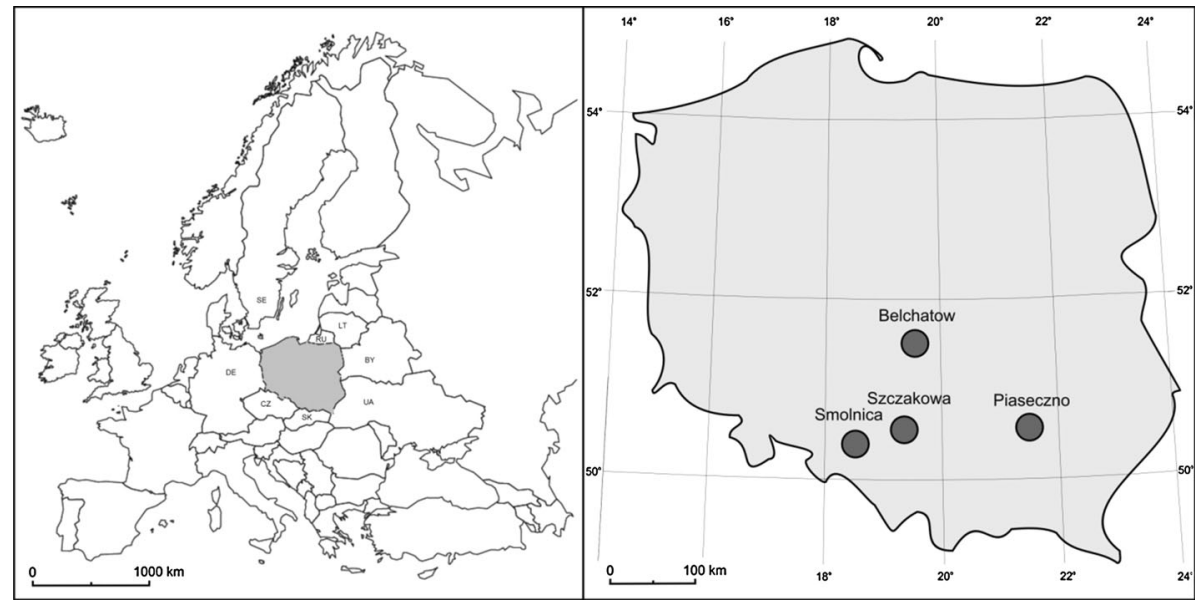

Fig. 1 Location of study sites

height was $14.1 \mathrm{~m}$ and varied from 9.9 to $19.5 \mathrm{~m}$. After cutting, age and height increment of each tree were estimated on the basis of distance between branch verticils.

\section{Soil sampling}

At each of the 28 study plots, five holes were bored using soil drills (from Eijkelkamp, diameter $8.5 \mathrm{~cm}$ ) for preparation of composed sample-four holes were drilled at the corners and one was taken from the interior of the square study plots. Samples (a total of 84 composed samples: 7 mine soil substrates $\times 4$ soil pit substrate replications $\times 3$ soil layers) were taken to determine the texture, basic chemical and biological soil characteristics from depths of: $0-8 \mathrm{~cm}$ (organic mineral horizons displaying some features of parent rock AC); 8-50 cm, and 50-110 $\mathrm{cm}$ (parent materials/rocky spoils $\mathrm{C}$ horizon).

\section{Laboratory soil analysis}

The soil samples were divided into two parts. One part (from the AC horizon) was immediately sieved $\left(2.0 \mathrm{~mm}\right.$ mesh size) and stored field-moist at $4{ }^{\circ} \mathrm{C}$ for microbial soil analysis (dehydrogenase activity DHG), while the other part was air-dried, sieved $(2.0 \mathrm{~mm}$ mesh size), finely ground and used for physico-chemical analyses. Basic soil parameters were determined from the soil samples using soil laboratory procedures (Ostrowska et al. 1991; Van Reewijk 2002): the soil texture of the samples was determined hydrometrically; the $\mathrm{pH}$ of the soil was measured with a combination electrode in suspensions of distilled water and $1 \mathrm{~mol} \mathrm{~L}^{-1} \mathrm{KCl}$ (1:2.5 mass/volume ratio) after $24 \mathrm{~h}$ equilibration (for $\mathrm{pH}_{\mathrm{KCl}}$ ). Contents of soil organic carbon (SOC) and total nitrogen (TN) were measured by dry combustion using the Leco CNS 2000 analyser. Samples containing $\mathrm{CaCO}_{3}$ were washed (after initial test with $\mathrm{HCl}$ ) in $10 \% \mathrm{HCl}$ to remove carbonates before $\mathrm{SOC}$ was determined. To measure exchangeable acidity, the samples $(40 \mathrm{~g})$ were treated with $1 \mathrm{~mol} \mathrm{~L}^{-1}$ $\mathrm{Ca}\left(\mathrm{CH}_{3} \mathrm{COO}\right)_{2}$ using 1:2.5 soil/solution ratio. Suspensions were shaken for $1 \mathrm{~h}$, filtered and titrated with $0.1 \mathrm{M} \mathrm{NaOH}$ to $\mathrm{pH}=8.2$. The exchangeable acidity was calculated from the amount of base used and expressed in $\mathrm{cmol}_{(+)} \mathrm{kg}^{-1}$. Exchangeable form cations $\left(\mathrm{Na}^{+}, \mathrm{K}^{+}\right.$, $\mathrm{Ca}^{2+}$ and $\mathrm{Mg}^{2+}$ ) were extracted with $1 \mathrm{~mol} \mathrm{~L}^{-1} \mathrm{NH}_{4} \mathrm{Oac}$ (at $\mathrm{pH}=7$ ). Samples were 


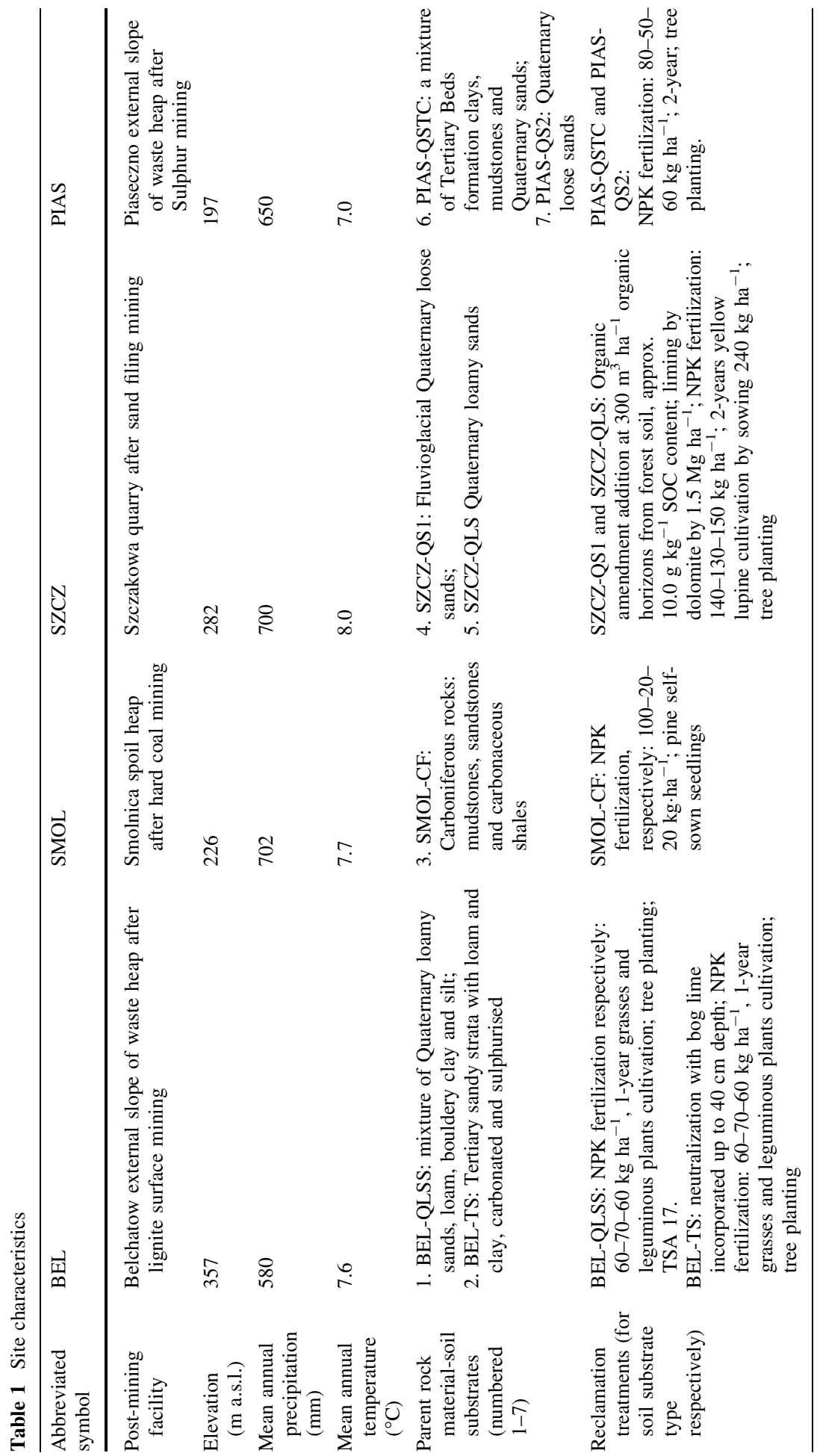


mixed with a small portion of extractant and equilibrated. After $24 \mathrm{~h}$, suspensions were filtered, soils were washed with additional extractant, and the total volume was made up to $100 \mathrm{~mL}$. The concentration of cations was determined by atomic absorption spectroscopy (AAS) with a Varian Spectrophotometer. Total Exchangeable Bases (TEB) were calculated as a sum of base cations $\left(\mathrm{Na}^{+}, \mathrm{K}^{+}, \mathrm{Ca}^{2+}, \mathrm{Mg}^{2+}\right)$. Cation exchange capacity (CEC) was defined as the equivalent sum of TEB and exchangeable acidity; the base saturation (BS\%) was defined as the equivalent sum of base cation percentage of CEC. Phosphorus in a form available to plants $\left(\mathrm{P}_{\mathrm{av}}\right)$ was assayed using the Egner-Riehm method in calcium lactate extract $\left(\left(\mathrm{CH}_{3} \mathrm{CHOHCOO}\right)_{2} \mathrm{Ca}\right)$ and acidified with hydrochloric acid to $\mathrm{pH} 3.6$ using a colorimetry method on a CARY 300 Conc UV-Visable Varian Spectrometer.

Dehydrogenase activity (DHG) in the soils was determined by reduction of 2,3,5triphenyltetrazolium chloride (TTC) following the method described in Casida et al. (1964). The soil samples ( $5 \mathrm{~g}$ ) were amended with $3 \mathrm{~mL}$ of $0.2 \mathrm{M} \mathrm{CaCO}_{3}$ and $1 \mathrm{~mL}$ of $3 \%$ TTC and incubated for $24 \mathrm{~h}$ at $37^{\circ} \mathrm{C}$. The triphenyl formazan (TPF) formed was extracted from the reaction mixture with methanol and assayed colorimetrically at $485 \mathrm{~nm}$.

Site index modeling

Recent work involves the development of site index models using three dimensional functions, which should provide numerous desirable characteristics (Nord-Larsen et al. 2009; Socha and Orzel 2013): (1) good fit of the modelled curves to empirical data; (2) polymorphism, which would take into account the possible differences in growth patterns resulting from variability in site conditions; (3) variable asymptotes for different sites; (4) equality of the site index and height at a certain base age; (5) the possibility of using the same function as a height growth and site index model; and (6) the possibility of biological interpretation of the parameters of the equation.

Following a review of the literature, two previously developed functions [Eqs. (1), $(1.1),(2)]$ were selected as starting points for the development of the local site index model used in this study. Some of the symbols used to represent variables and parameters in the original descriptions of these models are replaced below with the following standardised notations: $H_{1}$ represents the height at age $T_{1} ; H_{2}$ represents the height at age $T_{2} ; \beta_{1}, \beta_{2}$, and $\beta_{3}$ represent model parameters.

The first function considered is that of (Cieszewski 2001) (Eq. 1):

$$
H_{2}=H_{1} \frac{T_{2}^{\beta_{1}}\left(T_{1}^{\beta_{1}} R+\beta_{2}\right)}{T_{1}^{\beta_{1}}\left(T_{2}^{\beta_{1}} R+\beta_{2}\right)},
$$

where

$$
R=H_{1}-\beta_{3}+\left(\left(H_{1}-\beta_{3}\right)^{2}+\frac{2 \beta_{2} H_{1}}{T_{1}^{\beta_{1}}}\right)^{0.5}
$$

Cieszewski et al. (2007) used this function to describe the growth curves of Scots pine. The second function is that of Chapman-Richards (Tewari and Kishan Kumar 2002) (Eq. 2):

$$
H_{2}=H_{1} \cdot\left(\frac{1-e^{\beta_{1} \cdot T_{2}}}{1-e^{\beta_{1} \cdot T_{1}}}\right)^{\beta_{2} \cdot H_{1}^{\beta_{3}}}
$$


The parameters of the selected functions were calculated based on the heights of the analysed trees with the use of the base-age invariant (BAI) stochastic regression approach described by Strub and Cieszewski (2006). According to the BAI method, the site-specific local parameter of individual tree growth series $\left(\mathrm{H}_{1}\right)$ and common global parameters of the model $\left(\beta_{0}, \ldots, \beta_{n}\right)$ were estimated simultaneously. For data representing successive observations in time, especially when all possible time intervals are used, it is not unusual to observe autocorrelation of residuals, which interferes with a correct estimation of model parameters and their standard errors. This is due to the lack of independence between the observations in the estimation of model parameters (Parresol and Vissage 1998). To avoid this problematic phenomenon, the calculation of site index model parameters proceeded in two stages. In the first stage, it was calculated without taking into account the autocorrelation of residuals. Next, a model of autocorrelation was constructed, which was used in calculating the parameters in the final form of the site index model. In the case of a data structure with all possible pair values (age $-T$ and height $-H$ ), the random error $e_{i j}$ was modeled using a first order autocorrelation function (Socha and Orzeł 2013, Eq. 3).

$$
e_{i j}=\eta \cdot \rho \cdot \varepsilon_{i-1, j}+\mu \cdot \gamma \cdot \varepsilon_{i, j-1}+\varepsilon_{i, j}
$$

where: $\eta$ - a dummy variable taking a value of ' 0 ' if ' $i$ ' is the first observation that occurs in a given series and ' 1 ' in other cases, $\mu$ - a dummy variable taking a value of ' 0 ' if ' $j$ ' is the first observation in the series and ' 1 ' in other cases, $\rho$-an autocorrelation between the current residual and the residual from a designated $H_{i-1}$ on the basis of $H_{j}\left(\varepsilon_{i-1, j}\right), \gamma$-an autocorrelation between the current residual and a residual from a designated $H_{i}$ on the basis of $H_{j-1}\left(\varepsilon_{i, j-1}\right)$,

When using a data structure that includes all possible growth intervals, the number of observations is artificially inflated, thus the conventional standard errors of model parameters are underestimated (Goelz and Burk 1996). Therefore, standard errors were corrected using an expression taking into account the number of observations using all possible differences $(n(a p d))$ and the number of observations using only first differences $(n(f d))($ Eq. 4).

$$
e_{\exp }=\sqrt{\frac{n(a p d)}{n(f d)}}
$$

$n(a p d)$ - the number of observations using all possible differences (apd), $n(f d)$ - the number of observations using first difference $(f d)$

The selection of the best site index model was based on four statistical criteria that describe the accuracy of the fit of a model to empirical data (Palahi 2004):

- Mean error (ME, Eq. 5)

$$
M E=\frac{\sum_{i=1}^{n}\left(H_{i}-\hat{H}_{i}\right)}{n}
$$

where $H_{i}$, and $\hat{H}_{i}$ denote, respectively, observed and predicted tree heights and $n$ denotes the number of observations.

- Root mean square error (RMSE, Eq. 6) 


$$
R M S E=\sqrt{\frac{\sum_{i=1}^{n}\left(H_{i}-\hat{H}_{i}\right)^{2}}{n-p}}
$$

- Adjusted coefficient of determination (or model efficiency)

$$
R_{a d j}^{2}=1-\frac{\sum_{i=1}^{n}\left(H_{i}-\hat{H}_{i}\right)^{2}}{\sum_{i=1}^{n}\left(H_{i}-\bar{H}\right)^{2}}\left(\frac{n-1}{n-p-1}\right)
$$

- Distribution of residual values predicted by the models

In the next step of the analysis, site indices $(S I)$ for individual plots were calculated on the basis of height and age of the stands. Site indices were defined as the mean height of 500 thickest trees per ha $\left(H_{500}\right)$ at base age 25 years.

Statistical analyses

Multiple regression was used to describe the relationship between site index and independent variables such as RMS properties. It was necessary to transform some independent variables because of nonlinearity. Strong relationships between the independent variables, termed collinearity, cause the least squares regression coefficients to become unstable: coefficient standard errors are large, reflecting the imprecision of parameter estimation. Consequently, the parameter confidence intervals are broad. The impact of collinearity on the precision of estimation was captured by the variance inflation factor (VIF) (Fox 1991). VIF was calculated according to Eq. 8:

$$
V I F_{j}=\frac{1}{1-R_{j}^{2}}
$$

where $R_{j}^{2}$ is the coefficient of determination between independent variable $\mathrm{j}$ and other independent variables.

According to commonly accepted standards (Fox 1991) it was assumed that VIF value should not exceed a value of 2 . Homoscedasticity and the distribution of residual values against values predicted from the models were analysed graphically and tested using White's (1980) test. Logarithmic and square root data transformations were used in the case of absence of homoscedasticity. Statistical analyses of the results were done using STATISTICA (StatSoft 1984-2013) software. Independent variables, which to a large extent explain potential site, were selected on the basis of forward multiple regression analysis. These variables were used in developing geocentric regression equations describing site productivity for Scots pine on analysed afforested post-mine areas. One of the assumptions of multiple regression analysis is independence of individual observations, which may be violated in grouped data. Therefore the possibility of non-independence of grouped observations on given substrate types was addressed by entering the grouping factor as a set of dummy variables. Individual substrate types were considered as 7 dummy variables in the regression model in which Bel-TS substrate served as the baseline (reference) level. 


\section{Results}

\section{Soil characteristics}

Table 2 reports mean and range values of basic reclaimed mine soil (RMS) characteristics. The chemical and microbial properties of soil samples differed substantially for individual sample plots. For example, the percentage of sand in the $2.0-0.05 \mathrm{~mm}$ size fraction ranged from 40.0 to $97.0 \%$, silt sized fraction $(0.05-0.002 \mathrm{~mm})$ between 2.0 and $39.0 \%$ and clay sized fraction $(<0.002 \mathrm{~mm})$ between 1.0 and $26.0 \%$. Mean organic carbon SOC in the AC horizon (at $0-8 \mathrm{~cm}$ depth) varied on average between $2.3 \mathrm{~g} \mathrm{~kg}^{-1}$ (min: $1.5 \mathrm{~g} \mathrm{~kg}^{-1}$ ) (SZCZ-QS1 on sand mine cast) and $166.1 \mathrm{~g} \mathrm{~kg}^{-1}$ ( $\max 182.0 \mathrm{~g} \mathrm{~kg}^{-1}$ ) (SMOL-CF on hard coal mining spoil heap). Total nitrogen $\mathrm{N}_{\mathrm{t}}$ content in the $\mathrm{AC}$ horizon varied from a minimum of $0.12 \mathrm{~g} \mathrm{~kg}^{-1}$ to a maximum of $4.59 \mathrm{~g} \mathrm{~kg}^{-1}$; SOC-to-TN ratio in the AC horizon ranged on average between 7.3 (SSCZ-QS1) and 41.2 (SMOL-CF) with a minimum of 6.0 and a maximum of 42.7 (Table 2).

Soil $\mathrm{pH}$ ranged from 3.5 to 8.3 in $\mathrm{H}_{2} \mathrm{O}$ and 2.7 to 8.0 in $1 \mathrm{M} \mathrm{KCl}$. Dehydrogenase activity in samples taken from the AC horizon varied between 0.1 and $26.9 \mathrm{mg}$ TPF $100 \mathrm{~g}^{-1}$ soil $24 \mathrm{~h}^{-1}$, indicating large variability in the content of active microbial biomass. The samples differed considerably also in terms of their cation exchange properties. The exchangeable acidity (Hh) ranged from 0.4 to $16.7 \mathrm{cmol}_{(+)} \mathrm{kg}^{-1}$, Total Exchangeable Bases (TEB) from 0.4 to $33.3 \mathrm{cmol}_{(+)} \mathrm{kg}^{-1}$, Cation Exchangeable Capacity (CEC) from 1.2 to $33.9 \mathrm{cmol}_{(+)} \mathrm{kg}^{-1}$ and Base Saturation (BS) from 25.5 to $98.5 \%$. The content of available phosphorus $\left(\mathrm{P}_{\mathrm{av}}\right)$ ranged from 0.1 to $31.6 \mathrm{mg} \mathrm{kg}^{-1}$ and exchangeable potassium $\left(\mathrm{K}^{+}\right)$from 0.01 to $0.25 \mathrm{cmol}_{(+)} \mathrm{kg}^{-1}$ (Table 2).

Tree stand characteristics

The pine tree stands ranged in age from 12 (BEL-TS) to 30 years (PIAS-QSTC, PIAS-QS2 and SMOL-SF), and this has strongly affected the differentiation of stand characteristics. Table 3 reports mean and range values of basic tree stand characteristics. Average mean diameter at breast height (Dg) ranged from $2.9 \mathrm{~cm}$ (BEL-TS) to $19.1 \mathrm{~cm}$ (PIAS-QSTC); basal area (area of stand cross-section at breast height, G) ranged from $4.11 \mathrm{~m}^{2} \mathrm{ha}^{-1}$ (BEL-TS) to $30.64 \mathrm{~m}^{2} \mathrm{ha}^{-1}$ (PIAS-QS2). Average height (HL) ranged from $3.3 \mathrm{~m}$ (BELTS) to $16.2 \mathrm{~m}$ (PIAS-QSTC). Stand density expressed by the number of stems per ha ranged from 1,050 $\mathrm{pcs} \mathrm{ha}^{-1}$ (PIAS-QSTC) to 7,500 $\mathrm{pcs} \mathrm{ha}^{-1}$ (BEL-QLSS) (Table 3).

Developed site index models

Two basic site index models were developed (Fig. 2, Table 4) based on the parameter estimation of growth functions (Eqs. 1 and 2). These models show small differences in patterns of height growth due to the age of the stand as well as the site (Fig. 2). The model based on Eq. 1 had a slightly lower value of RMSE error and explained a larger portion of variance. Therefore, the site index model developed from Eq. 1 (Eq. 9) was used for calculating site index for individual sample plots.

$$
S I=H_{500} \frac{25^{1.82014}\left(T^{1.82014} R+16178.3\right)}{T^{1.82014}\left(25^{1.82014} R+16178.3\right)},
$$

where 


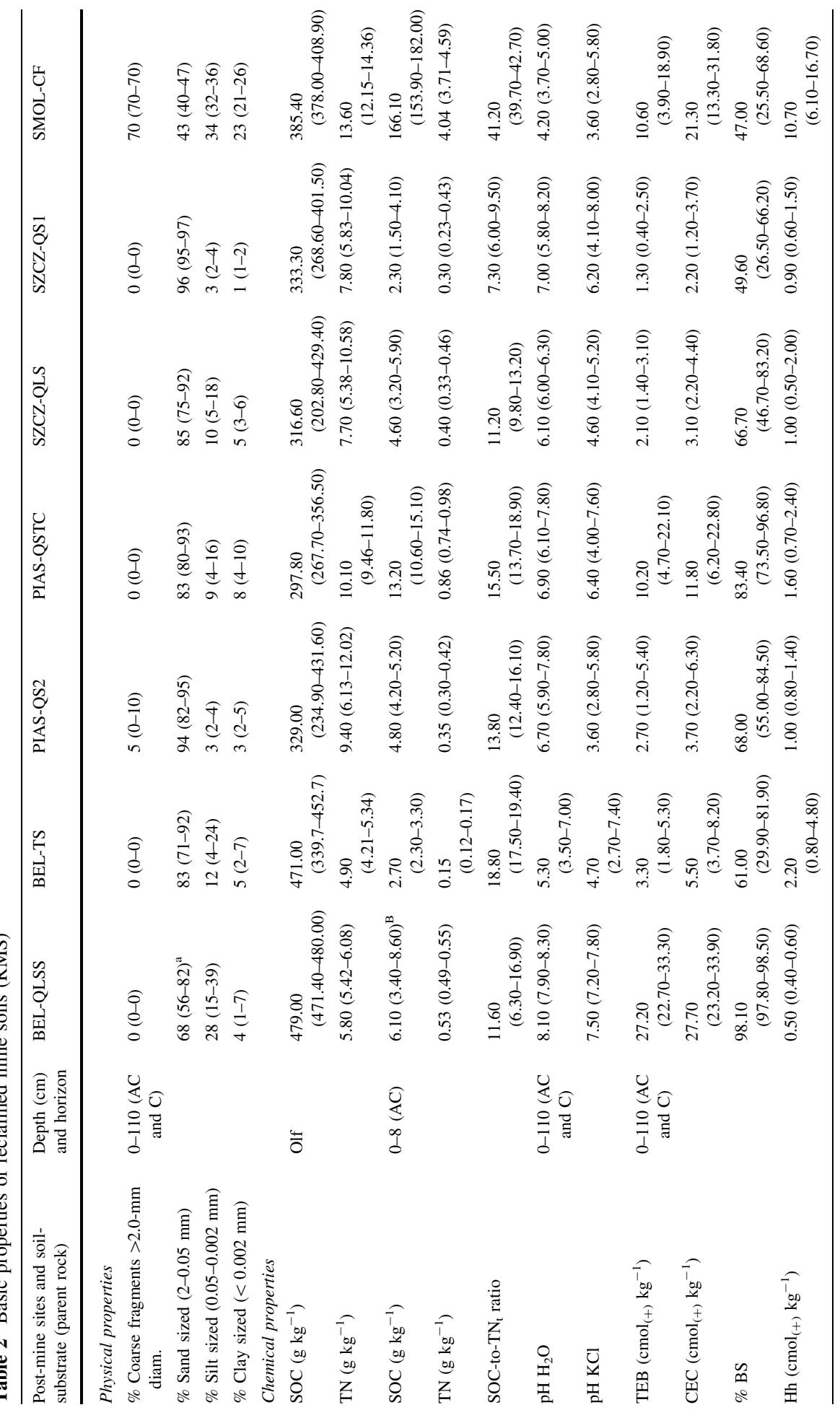




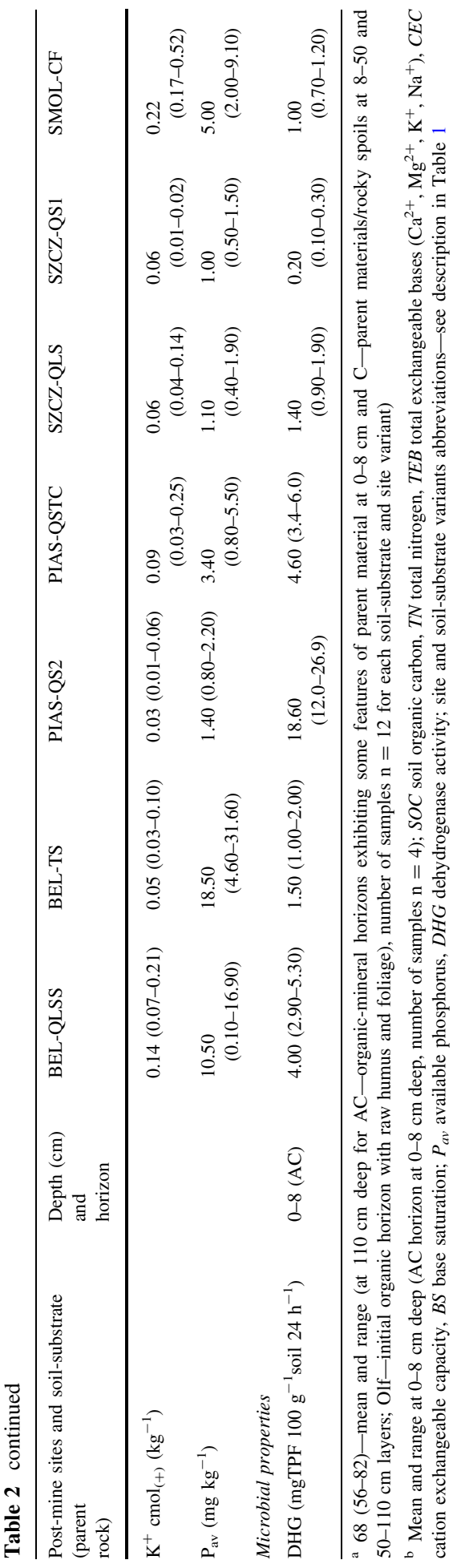




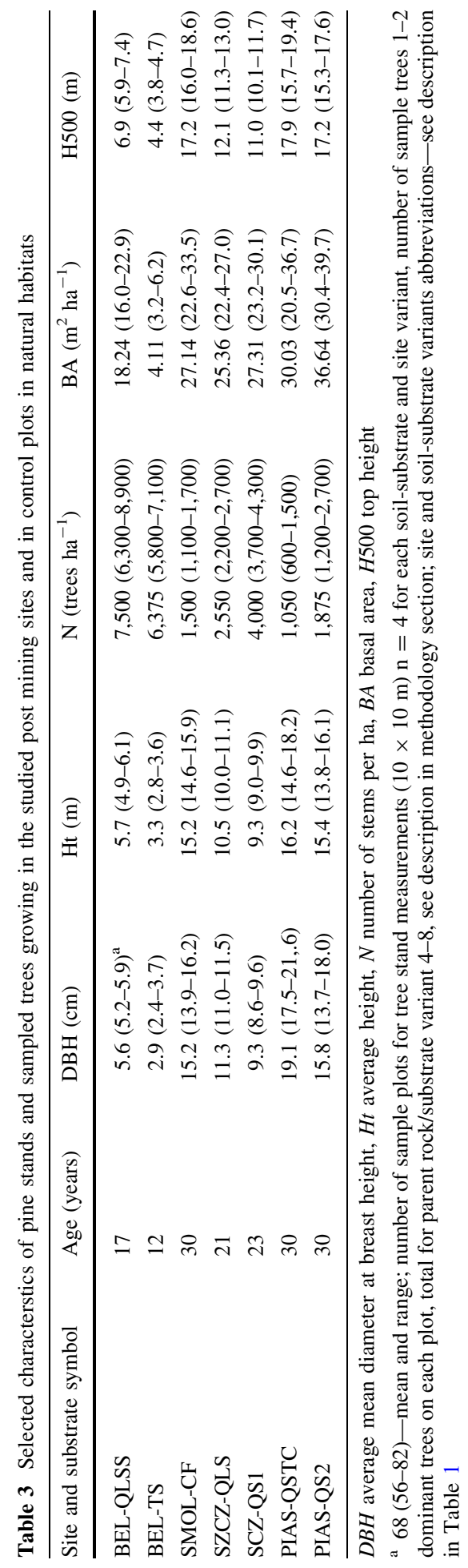




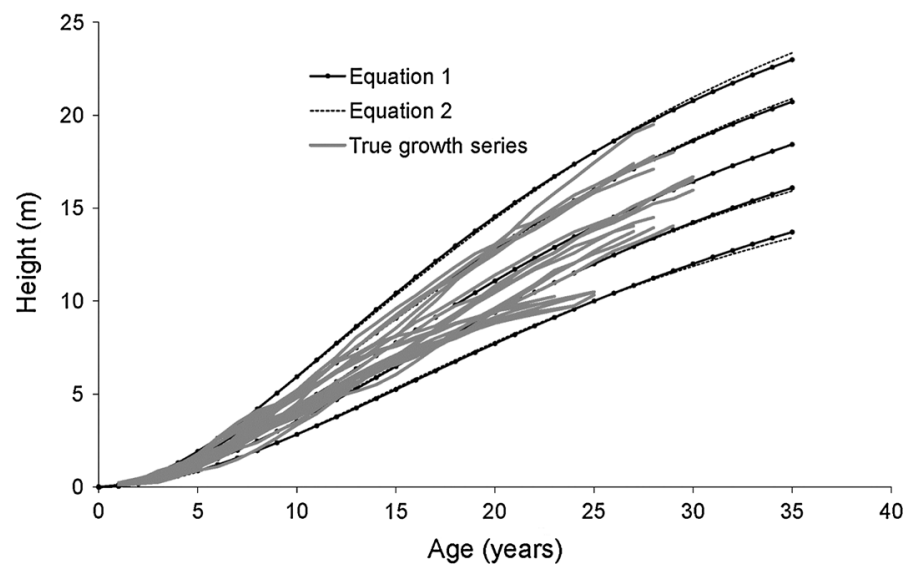

Fig. 2 Model site index curves fitted according to Cieszewski (Eq. 1) and Chapman-Richards (Eq. 2) functions and true growth series of individual trees. Numbers refer to height at base age 25 years

Table 4 Parameter estimates and basic statistics for two developed site index models for Scots pine from post mining reclaimed areas

\begin{tabular}{llllrrrr}
\hline No equation & Parameter & $\begin{array}{l}\text { Value of } \\
\text { parameter }\end{array}$ & $\begin{array}{l}\text { Standard } \\
\text { error }\end{array}$ & t-statistics & $p$ level & RMSE & $\mathrm{R}^{2}$ \\
\hline Cieszewski & $\mathrm{b} 1$ & 1.82014 & 0.03042 & 59.83 & $<0.00001$ & 0.1143 & 0.99584 \\
(Equation 1) & $\mathrm{b} 2$ & $16,178.3$ & $5,881.35$ & 2.75 & $<0.00001$ & & \\
& $\mathrm{~b} 3$ & 8.48968 & 7.81282 & 1.09 & 0.27797 & & \\
Ch-R & $\mathrm{b} 1$ & -0.20408 & 0.05431 & -3.76 & 0.00020 & 0.1162 & 0.99577 \\
(Equation 2) & $\mathrm{b} 2$ & -0.05597 & 0.00243 & -23.06 & $<0.00001$ & & \\
& $\mathrm{~b} 3$ & 3.57278 & 0.52733 & 6.78 & $<0.00001$ & & \\
\hline
\end{tabular}

$$
\begin{gathered}
R=Z_{0}+\left(Z_{0}^{2}+\frac{2 \cdot 16178.3 \cdot H_{500}}{T^{1.82014}}\right)^{0.5}, \\
Z_{0}=H_{0}-8.48968
\end{gathered}
$$

$\mathrm{H}_{500}$ - top height calculated for sample plot on the basis of 5 thickest trees, $\mathrm{T}$ - denotes age of the stand on sample plot, SI-site index.

SI was characterized by relatively high variability. The coefficient of variation, which was calculated as the quotient of standard deviation and mean value, was $25.4 \%$ for all sites, whereas values of SI on individual sample plots varied from 5.8 to $17.0 \mathrm{~m}$ (Table 5). There were significant differences between mean SI values for individual site and substrate combinations (ANOVA, $p<0.001$ ). On the basis of the Scheffe post hoc test, site and substrate combinations were assigned to four homogenous groups (Table 5).

Relationships between mine soil properties and site index

From the point of view of pine growth productivity on mine sites, the best conditions (SI: $13.5-15.3 \mathrm{~m}$ ) were in Quaternary loamy (SZSZ-QLS), loose sands (PIAS-QS2), mixtures 
Table 5 Characteristics of SI on individual site and substrate combinations and homogenous groups according to Scheffe post hoc test

\begin{tabular}{llllrr}
\hline $\begin{array}{l}\text { Site and substrate } \\
\text { symbol }\end{array}$ & $\begin{array}{l}\text { Mean value }(\mathrm{m}) \text { and } \\
\text { homogeneous groups } \\
(\alpha=0.05)\end{array}$ & $\begin{array}{l}\text { Number of sample } \\
\text { plots }\end{array}$ & $\begin{array}{l}\text { Standard } \\
\text { deviation }(\mathrm{m})\end{array}$ & $\begin{array}{l}\text { Min } \\
(\mathrm{m})\end{array}$ & $\begin{array}{l}\text { Max } \\
(\mathrm{m})\end{array}$ \\
\hline BEL-TS & $6.4^{\mathrm{a}}$ & 4 & 0.66 & 5.8 & 7.1 \\
BEL-QLSS & $10.2^{\mathrm{b}}$ & 4 & 0.97 & 9.2 & 11.3 \\
SCZ-QS1 & $11.7^{\mathrm{bc}}$ & 4 & 0.67 & 11.2 & 12.6 \\
SZCZ-QLS & $13.5^{\mathrm{cd}}$ & 4 & 0.54 & 13.0 & 14.3 \\
PIAS-QS2 & $14.9^{\mathrm{d}}$ & 4 & 0.65 & 13.9 & 15.3 \\
PIAS-QSTC & $14.9^{\mathrm{d}}$ & 4 & 1.48 & 13.7 & 17.0 \\
SMOL-CF & $15.3^{\mathrm{d}}$ & 4 & 0.49 & 14.7 & 15.8 \\
Total & $12.4^{\mathrm{d}}$ & 28 & 3.15 & 5.8 & 17.0 \\
\hline
\end{tabular}

The letters a, b, c, d indicate probability level at $P=0.05$

of Tertiary clays, Quaternary sands (PIAS-QSTC) and Carboniferous deposits (SMOL$\mathrm{CF}$ ). Significantly lower SI values (10.2 and $11.7 \mathrm{~m}$ respectively) were found on mixtures of Quaternary loamy sands, loam, bouldery clay and silt (BEL-QLSS) and Fluvioglacial Quaternary loose sands (SZCZ-QS1). The worst conditions for pine growth occurred in the Tertiary sulphurised sandy strata (BEL-TS) where SI was a mere $6.4 \mathrm{~m}$ (Table 5).

Models developed from a number of soil characteristics in different soil layers $(0-8 \mathrm{~cm}$ AC horizon, 8-50 and 50-110 cm C horizons) explained from 56 to $85 \%$ of the SI variability. Site index was modeled as a function of $A C$ horizon $(0-8 \mathrm{~cm}$ deep) properties such as content of available phosphorus (variable $\mathrm{P}_{\mathrm{av} \_\mathrm{AC}}$ ), clay sized fraction content (variable Clay\% <0.002_AC) and $\mathrm{pH}_{\mathrm{H} 20 \_\mathrm{AC}}(\mathrm{Eq} .10)$, which explained over $56 \%$ variability of SI $(\mathrm{SEE}=2.08 \mathrm{~m})$.

$$
S I=7.2047-201.876 \times P_{a v \_A C}+0.226 \times C l_{a y}<0.002 \_A C+0.923 \times p H_{H_{2} O \_A C}
$$

However, in the case of available phosphorus $\left(\mathrm{P}_{\mathrm{av}}\right)$, these relationships were unexpectedly negative. Errors in SI estimation were characterised by homoscedasticity with extreme values varying from -3.39 to $3.36 \mathrm{~m}$.

The soil depth at which variables were measured mattered in explaining the variance of the regression models. The incorporation of $\mathrm{pH}$ from deeper $\mathrm{C}$ horizon at 8-50 $\mathrm{cm}$ layer (variable $\mathrm{pH}_{\mathrm{H} 2 \mathrm{O} \_\mathrm{C} 8-50 \mathrm{~cm}}$ ) instead of from the AC horizon (variable $\mathrm{pH}_{\mathrm{H} 20 \_\mathrm{AC}}$ ) increased the explained variance to $72.6 \%\left(\mathrm{R}_{\mathrm{adj}}^{2}=0.726\right)$. The inclusion of available phosphorus in the 8-50 cm layer $\left(P_{a_{2} C} 8-50 \mathrm{~cm}\right)$ increased explained variance to $77 \%\left(R_{a d j}^{2}=0.771\right)$. Strong collinearity was observed in the case of $\mathrm{P}$ from the AC horizon and 8-50 cm depth. Therefore, the value of $\mathrm{P}$ from the $8-50 \mathrm{~cm}$ layer replaced the value of $p$ from the AC horizon in the equation. Explained variance increased to $81 \%\left(R_{a d j}^{2}=0.8077\right)$ by including base saturation in the deeper $\mathrm{C}$ horizon in the $50-110 \mathrm{~cm}$ layer (variable $\mathrm{BS}$ $\left.(\%) \_50-110 \mathrm{~cm}\right)$. In this case, $\mathrm{pH}$ from both the $\mathrm{AC}(0-8 \mathrm{~cm}$ deep) and $\mathrm{C}$ horizons $(8-50 \mathrm{~cm})$ became insignificant.

After analysing all possible combinations of independent variables describing soil characteristics and substrate type, it was evident that site index depends mostly $\left(\mathrm{R}_{\mathrm{adj}}^{2}=0.8540\right)$ on clay sized fraction content in $0-8 \mathrm{~cm}$ of soil (Clay\%<0.002_AC), avail-

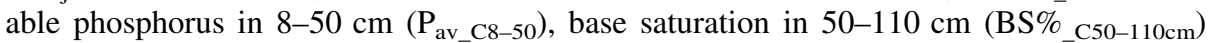
and exchangeable potassium in $50-110 \mathrm{~cm}\left(\mathrm{~K}^{+} \_\right.$C50-110cm $)$(Eq. 11). Substrate types 
expressed by dummy variables became insignificant once these variables were included in the regression model together with other soil characteristics selected during multiple regression analysis. Equation 11 explained over $85 \%\left(\mathrm{R}_{\mathrm{adj}}^{2}=0.854\right)$ of the variability in SI. Extreme residual SI values calculated using Eq. 6 ranged from -2.05 to $1.83 \mathrm{~m}$ with a standard deviation of $1.19 \mathrm{~m}$. In this model, as in the model described by Eq. 5, both $\mathrm{P}_{\mathrm{av}}$ and $\mathrm{K}(+)$ parameters in the multiple regression models were negative.

$$
\begin{aligned}
S I= & 9.242+0.285 \times \text { Clay }_{\%<0.002 A C}-167.911 \times P_{a v \_C 8-50 \mathrm{~cm}}+0.059 \\
& \times B S(\%)_{C 50-110 \mathrm{~cm}}-22.46 \times K(+)_{C 50-110 \mathrm{~cm}}
\end{aligned}
$$

Further data analysis revealed that the negative correlation of SI with high concentrations of phosphorus $\left(\mathrm{P}_{\mathrm{av}}\right)$ and potassium $(\mathrm{K}+)$ was connected with mine soils on Belchatow (BEL) spoil heap. The observed negative correlation of SI with $\mathrm{P}_{\mathrm{av}}$ and $\mathrm{K}+$ may not be explained by the existence of multicollinearity. Although there was some multicollinearity observed between variables presented in Eq. 11, variance inflation factors (VIF's) describing multicollinearity for individual variables in each instance were significantly lower than 4 (VIF $=2.35$ for Clay\%; 1.09 for $\mathrm{P}_{\mathrm{av}} ; 1.14$ for $\mathrm{BS} \%$, and 2.34 for $\mathrm{K}+$ ), which is 1 generally assumed to be the critical value (Fox 1991). After excluding this sample, the relationship between $\mathrm{SI}$ and $\mathrm{P}_{\mathrm{av}}$ became positive, whereas the relationship between SI and $\mathrm{K}(+)$ became insignificant. Eventually the multiple regression model which excluded the mine soil data collected in Belchatow explained about $62 \%$ of variability in the relationship between SI and soil properties (Eq. 12).

$$
\begin{aligned}
S I= & 10.24+0.1048 \times \text { Clay }_{\%<0.002 A C}+243.71 \times P_{a v} \_C 8-50 \mathrm{~cm} \\
& \times D H G_{A C}+0.0278 \times B S(\%)_{50-110 \mathrm{~cm}}
\end{aligned}
$$

In this case, $\mathrm{SI}$ is a function of clay sized fraction content in AC horizon in $0-8 \mathrm{~cm}$ deep (Clay\%<0.002AC), available phosphorus in $8-50 \mathrm{~cm}\left(\mathrm{P}_{\mathrm{av} \_\mathrm{C} 8-50}\right)$, base saturation in 50-110 cm (BS $\left.(\%) \_50-110 \mathrm{~cm}\right)$, and dehydrogenase activity in the AC horizon at $0-8 \mathrm{~cm}$ depth $\left(\mathrm{DHG}_{\mathrm{AC}}\right)$.

\section{Discussion}

Our study has shown a strong correlation of several basic soil properties with potential tree growth and site productivity in the early stage of pedogenesis. This allows for a fairly accurate prediction of the course of growth in pine stands for at least 25-30 years. In addition, knowledge of site productivity for Scots pine derived from mine soil characteristics at different deposits and parent rock, makes it possible to assess this species suitability for afforestation of individual post-mine facilities. Torbert et al. (1990) have shown usefulness of SI modeling for assessing pine growth variation associated with overburden rock type on a reclaimed surface mine in Virginia. A critical approach to the subject, however, makes note that in this study the data were collected from stands not exceeding 30 years of age. As a result, forecasting further growth in pine stands is subject to uncertainty, which arises from conditions in emerging ecosystems which are different than those of natural forest sites (Knoche 2005; Rodrigue et al. 2002; Pietrzykowski 2010, 2014). Nevertheless, the mere possibility of predicting the growth of pine in a short 20-30 year time horizon remains important for planning and carrying out rehabilitation of 
forests. It is in this time period that it is possible to restore habitat and initiate soil-forming processes by introducing pioneer species with relatively small habitat requirements and to plan for monoculture conversion to mixed forests in the next generation of tree stands (Knoche 2005; Pietrzykowski 2014). The appropriate moment for planning the reconstruction of the species composition, especially the transformation of introduced monocultures, is in the first generation stand while the assessment of habitat conditions forming under dynamic process of ecosystem succession is possible (Knoche 2005). Another advantage of the developed SI is that it is based on trees growing on geological deposits, which are dominant in mining sites affected by lignite, hard coal, sand and sulphur strip mining exploitation across Central Europe. Thus the relationships between tree growth and initial mine soil properties can be applied to predict the pine growth potential on other reclaimed lands in this region and used as a template for site productivity modeling on mine sites reclaimed to forest.

In Northern America and Europe top height is most commonly calculated on the basis of 100 of the largest DBH trees per hectare. In small sample plots this calculation of top height is strongly dependent on plot area, DBH and tree height variability (García 2010; Sharma et al. 2002). Therefore, in our study of relatively young stands and small sample plots, top height was adjusted to be the mean height of the 5 largest-diameter trees per 0.01 ha plot. Site index base age was defined as 25 years because of an assumed relatively young age of the stands. Similar base age was used in assessment of potential site productivity for afforested coalmined areas in the eastern United States (Torbert and Burger 2000).

Deposits consisting of parent rock on post-mining sites are formed from various substrates associated with lignite, hard coal and mineral mining extraction (in this case: Quaternary, Tertiary and Carboniferous strata). As mentioned before, the post-mine site conditions on which pines grow are different from natural forest habitats (Knoche 2005; Rodrigue et al. 2002; Baumann et al. 2006; Pietrzykowski 2010; Pietrzykowski et al. 2011; Pietrzykowski et al. 2013). Our results show that with respect to pine growth productivity, mine sites with Quaternary loamy and loose sands, mixtures of Tertiary clays, and Carboniferous deposits represent good conditions. On the above mentioned substrates, site productivity for Scots pine as expressed by site index was unexpectedly higher than mean site indices observed in natural stands located in surrounding areas. The worst conditions for pine growth are in the Tertiary sulphurised sandy strata. However, in this extreme habitat there are few alternatives in the choice for species composition, and Scots pine is one of the most important species during the first stage of ecosystem development.

Soil texture is one of the most important criteria for the classification of soil deposits and the assessment of site conditions for growth of trees on mine sites (Andrews et al. 1998; Gale et al. 1991). This feature is strongly connected to and is decisive for other soil properties (Burger and Kelting 1999). Our analysis shows that among various fractions in soil particle size distribution, the most important role is played by silt and clay. It is widely known that the above mentioned characteristics are closely linked with properties of the sorption complex, including the base saturation and ion-exchange mechanism, both key determinants of mineral nutrition in trees (Baule and Fricker 1970; Marschner 1995). However, it seems that the positive effect of clay sized fraction content in initial RMS is connected foremost to improved soil moisture regime by sorption of water (Burger and Kelting 1999; Socha 2012) while its nutritive role is of lower importance (Sewerniak 2012).

An important factor determining various soil properties, especially on acidic and sulphurized tertiary sand strata, is the type of reclamation treatment that is applied, such as neutralization with bog lime (rich in calcium $\mathrm{Ca}^{2+}$ and available phosphorus $\mathrm{P}_{\mathrm{av}}$; Table 1). Our analysis leads to the conclusion that even after the effects of treatment type, some 
mine soil properties themselves still clearly affect pine growth. In the analyzed mine soils, site index was not correlated with soil $\mathrm{N}$ content and was unexpectedly negatively correlated with soil $\mathrm{P}_{\mathrm{av}}$ and $\mathrm{K}^{+}$. Phosphorus and potassium, in addition to nitrogen, are the most deficient elements in reclaimed sites (Andrews et al. 1998; Marrs 1989; Marrs and Bradshaw 1993). These three elements most often constitute the limiting factor in nutrition of forest stands. The lack of statistically significant relationships between pine site index and $\mathrm{N}$ content in the soil can be explained in two ways. First, the amount of nitrogen acquired by a plant depends not only on in the amount of total nitrogen in the soil, but on the bioavailability of the element (Janssen et al. 1990; Smaling and Janssen 1993; Janssen 1996). Secondly, a very important factor influencing the relationships between soil nitrogen and site index is the existence of high $\mathrm{N}$ content in geogenic forms found in fossil coal in carboniferous deposits, e.g. Smolnica spoil heap (SMOL-CF). Typically, carbonates and geogenic $\mathrm{C}$ and $\mathrm{N}$ constitute large amounts of the original spoil banks but the bioavailability of geogenic $\mathrm{N}$ from coal spoils to plants has been debated (Cornwell and Stone 1968; Anderson 1977; Aldag and Strzyszcz 1980; Waschkies and Hüttl 1999). In our study, mine soils developing from these deposits have very high nitrogen and carbon content (means: $0.404 \mathrm{~g} \mathrm{~kg}^{-1} \mathrm{~N}_{\mathrm{t}}$ and $16.61 \mathrm{~g} \mathrm{~kg}^{-1} \mathrm{SOC}$, respectively; Table 2). As mentioned, these values must be considered with respect to the origin and properties of these deposits. When geogenic $\mathrm{C}$ constitute large amounts of the original spoils bank, it is methodologically difficult to determine the organic $\mathrm{C}$ content and accumulation rate in initial RMS and even more difficult to determine the SOC stock (Vindušková and Frouz 2012). In this study we did not address the relationships between fossil (geogenic) carbon, current soil organic carbon and the general status of carbon in mining soils. Rather, the focus of our work was on the assessment of tree growth on current site conditions. The question of fossil carbon and nitrogen assimilation by soil biota and eventually by plants during mine soil forming processes remains for another study (Waschkies and Hüttl 1999; Frouz et al. 2006, 2007).

Quite unexpectedly, SI was negatively correlated with P and K content in the mineral soil horizon due to the fact that pine growth contributing to the lowest values of SI occurred on Tertiary, sulphurized and acidic strata neutralized with bog lime (BEL-TS). Apart from a disturbance of element relationships in RMS developed originally on Tertiary strata, there may also be excessive concentrations of sulphur by pyrite oxidation and acid mine drainage (Katzur and Haubold-Rosar 1996). In a way, in the case of sandy soils developed on Tertiary strata, neutralisation by bog lime improved the $\mathrm{P}$ and $\mathrm{K}$ content because this sediment contains phosphorus and potassium bound by organic fossil residue from the bottom of tertiary lakes. However, this soil still has numerous features which limit good nutrient conditions for trees (Heinsdorf 1996; Katzur and Haubold-Rosar 1996; Knoche 2005; Pietrzykowski et al. 2013). The unexpected negative response of pine growth on $\mathrm{P}$ and $\mathrm{K}$ content in mining soils can also suggest that there are other factors stronger than nutrient content (especially $\mathrm{P}$ and $\mathrm{K}$ ) affecting tree growth. For example, the disturbance in availability and plant nutrient supply could be affected by $\mathrm{pH}$, soil sorption complex and nutrient relationships in soil. A comparison of results from mine sites afforested with pine and reference data from natural forests (Pietrzykowski 2010, 2014) shows that macronutrient ratios in soil and biomass (particularly the relationship of nitrogen to other nutrients) have been disturbed at mine sites. The nutrient imbalance is evidence that conditions in reclaimed soils are different from natural sites, necessitating the adaptation of a strategy in which nutrient availability is considered in afforestation planning (Knoche et al. 2002; Pietrzykowski 2010). An additional factor to consider when interpreting the complex response of pine growth to mine sites is that Scots pine is oligotrophic (Farjon 2005), suggesting that nutrient-rich RMS, as in the example of 
increased $\mathrm{P}$ and $\mathrm{K}$ content resulting from the application of bog lime on Tertiary strata, do not promote pine tree stand growth and stability (Pietrzykowski 2014).

\section{Conclusions}

The site index prediction model with the best fit to the data (expressed by Eq. 7) explained a relatively large part (greater than $60 \%$ ) of SI variability, even though our study presented the challenge of creating a site index for mine soil substrates developed on Quaternary, Tertiary and Carboniferous strata with a range of physico-chemical and biological properties. The SI model allows the ability to explain pine productivity on analyzed substrates by considering clay sized fraction content, base saturation, available phosphorus, and dehydrogenase activity.

With site index prediction models describing relationships between site index and soilsubstrate properties, it is possible to assess the growth potential and forecast the growth pattern and productivity for specified species on post mine sites, especially in sites that are similar in characteristics to the sites from which data for model development were obtained. Developed models were specified for 8 types of substrates occurring in analysed post-mining areas. The planning of mine reclamation to forest benefits from robust estimates of potential site productivity. Since RMS are characterized by large variability, it is rather difficult and likely ineffective to develop one universal productivity model for all species used in afforestation efforts. Therefore, future studies should model potential site productivity for tree species other than Scots pine.

Acknowledgments This study was financially supported by the Polish Ministry of Science and Higher Education Grant No 309013 32/2076 and partly by statutory financial support of Ministry of Science and Higher Education RP (DS-3420/KEkL/2014 Department of Forest Ecology and DS-3418/KD/2014 Department of Biometry and Forest Productivity, University of Agriculture in Krakow).

Open Access This article is distributed under the terms of the Creative Commons Attribution License which permits any use, distribution, and reproduction in any medium, provided the original author(s) and the source are credited.

\section{References}

Aldag RW, Strzyszcz Z (1980) Inorganic and organic nitrogen compounds in carboniferous phyllosilicates on spoils with regard to forest reclamation. Reclame Rev 3:69-73

Anderson DW (1977) Early stages of soil formation on glacial till mine spoils in a semi-arid climate. Geoderma 19:11-19

Andrews JA, Johnson JE, Torbert JL, Burger JA, Kelting DL (1998) Minesoil and site properties associated with early height growth of Eastern White pine. J Environ Qual 27:192-199

Baule H, Fricker C (1970) The fertilizer treatment of forest trees. English edition: Die Düngung v. Waldbäumen (trans: Whittles CL). BLV Verlagsgesellschaft, München

Baumann K, Rumpelt A, Schneider BU, Marschner P, Hüttl RF (2006) Seedling biomass and element content of Pinus sylvestris and Pinus nigra grown in sandy substrates with lignite. Geoderma 136:573-578

Bošela M, Petráš R, Šmelko Š (2011) Site classification vs. wood production: a case study based on Silver fir growth dynamics in the Western Carpathians. J For Sci 57:409-421

Bradshaw AD (1983) The reconstruction of ecosystems. J Appl Ecol 20:1-17

Burger JA, Kelting DL (1999) Using soil quality indicators to assess forest stand management. For Ecol Manage 122:155-166

Casida L, Klein D, Santoro T (1964) Soil dehydrogenase activity. Soil Sci 98:371-376 
Cieszewski CJ (2001) Three methods of deriving advanced dynamic site equations demonstrated on inland Douglas-fir site curves. Can J For Res 31:165-173

Cieszewski CJ, Strub M, Zasada M (2007) New dynamic site equation that fits best the Schwappach data for Scots pine (Pinus sylvestris L.) in Central Europe. For Ecol Manage 243:83-93

Cornwell SM, Stone EL (1968) Availability of nitrogen to plants in acid coal mine spoils. Nature 217:768-769

Farjon A (2005) Pines: drawings and descriptions of the genus pinus. 2nd revised edn. Brill, Leiden

Fox J (1991) Regression diagnostics: quantitative applications in the social sciences. Sage Univ Paper 7:1-92

Franklin JA, Zipper CE, Burger JA, Skousen JG, Jacobs DF (2012) Influence of herbaceous ground cover on forest restoration of eastern US coal surface mines. New For 43:905-924

Frouz J, Elhottová D, Kuráž V, Šourková M (2006) Effects of soil macrofauna on other soil biota and soil formation in reclaimed and unreclaimed post mining sites: results of a field microcosm experiment. Appl Soil Ecol 33:308-320

Frouz J, Elhottová D, Pižl V, Tajovský K, Šourková M, Picek T, Malý S (2007) The effect of litter quality and soil faunal composition on organic matter dynamics in post-mining soil: a laboratory study. Appl Soil Ecol 37:72-80

Gale MR, Grigal DF, Harding RB (1991) Soil productivity index: predictions of site quality for white spruce plantations. Soil Sci Soc Am J 55:1701-1708

García O (2010) Dynamical implications of the variability representation in site-index modelling. Eur J For Res 130:671-675

Goelz JCG, Burk TE (1996) Measurement error causes bias in site index equations. Can J For Res 26:1585-1593

Hägglund B, Lundmark JE (1977) Site index estimation by means of site properties of Scots pine and Norway spruce in Sweden. Stud For Suec 138:5-38

Heinsdorf D (1996) Development of forest stands in the Lusatian Lignite Mining District after mineral fertilization adopted to site and tree species. Water Air Soil Pollut 91:33-42

Janssen BH (1996) Nitrogen mineralization in relation to $\mathrm{C}: \mathrm{N}$ ratio and decomposability of organic materials. Plant Soil 181:39-45

Janssen BH, Guiking FCT, van der Eijk D, Smaling EMA, Wolf J, van Reuler H (1990) A system for quantitative evaluation of the fertility of tropical soils (QUEFTS). Geoderma 46:299-318

Johansson T (1995) Site index curves for Norway spruce plantations on farmland with different soil types. Stud For Suec 198:1-19

Katzur J, Haubold-Rosar M (1996) Amelioration and reforestation of sulfurous mine soils in Lusatia (Eastern Germany). Water Air Soil Pollut 91:17-32

Knoche D (2005) Effects of stand conversion by thinning and underplanting on water and element fluxes of a pine ecosystem (P. sylvestris L.) on lignite mine spoil. For Ecol Manage 212:214-220

Knoche D, Embacher A, Katzur J (2002) Water and element fluxes of red oak ecosystems during stand development on post-mining sites (Lusatian Lignite District). Water Air Soil Pollut 141:219-231

Kuznetsova T, Mandre M, Klõseiko J, Pärn H (2010) A comparison of the growth of Scots pine (Pinus sylvestris L.) in a reclaimed oil shale post-mining area and in a Calluna site in Estonia. Environ Monit Assess 166:257-265

Marrs RH (1989) Nitrogen accumulation, cycling and the restoration of ecosystems on derelict land. Soil Use Manag 5:127-134

Marrs RH, Bradshaw AD (1993) Primary succession on man-made wastes: the importance of resource acquisition. In: Miles J, Walton DWH (eds) Primary succession on land. Blackwell Scientific Publications, Oxford, pp 221-248

Marschner H (1995) Mineral nutrition of higher plants. Academic Press, Cambrige

Nord-Larsen T, Meilby H, Skovsgaard JP (2009) Site-specific height growth models for six common tree species in Denmark. Scand J For Res 24:194-204

Ochał W, Pająk M, Pietrzykowski M (2010) Diameter structure of selected pine stands growing on postmining sites reclaimed for forestry (in Polish, English summary). Sylwan 154:323-332

Ostrowska S, Gawlinski Z, Szczubialka Z (1991) Procedures for soil and plants analysis. Institute of Environmental Protection, Warsaw

Palahi M, Tome M, Pukkala T, Trasobares A, Montero G (2004) Site index model for Pinus sylvestris in north-east Spain. For Ecol Manag 187(1):35-47

Parresol BR, Vissage JS (1998) White pine site index for the southern forest survey. Research Paper SRS10. Asheville, NC: U.S. Department of Agriculture, Forest Service, Southern Research Station. $10 \mathrm{p}$

Pietrzykowski M (2010) Scots pine (Pinus sylvestris L.) ecosystem macronutrients budget on reclaimed mine sites—-stand trees supply and stability. Nat Sci 02:590-599 
Pietrzykowski M (2014) Soil quality index as a tool for Scots pine (Pinus sylvestris) monoculture conversion planning on afforested, reclaimed mine land. J For Res 25(1):63-74

Pietrzykowski M, Krzaklewski W (2007) An assessment of energy efficiency in reclamation to forest. Ecol Eng 30:341-348

Pietrzykowski M, Socha J (2011) An estimation of Scots pine (Pinus sylvestris L.) ecosystem productivity on reclaimed post-mining sites in Poland (central Europe) using of allometric equations. Ecol Eng 37:381-386

Pietrzykowski M, Pająk M, Krzaklewski W (2011) Assesment of soil-site conditions on the spoil heaps of Lignite Mining Plant (KWB) "Bełchatów" reclaimed to forest with the use of the Site Soil Index (SIG). Pol J Soil Sci 54:81-88

Pietrzykowski M, Woś B, Haus N (2013) Scots pine needles macronutrient (N, P, K, Ca, Mg, and S) supply at different reclaimed mine soil substrates-as an indicator of the stability of developed forest ecosystems. Environ Monit Assess 185:7445-7457

Rodrigue JA, Burger JA, Oderwald RG (2002) Forest productivity and commercial value of pre-law reclaimed mined land in the eastern United States. North J Appl For 19:106-114

Sewerniak P (2012) Impact of soil properties on site index class of Scots pine (Pinus sylvestris L.) stands in south-western Poland. I. pH, content of $\mathrm{CaCO} 3$, and properties concerning soil depth. (in Polish, English summary). Sylwan 156:427-436

Sharma M, Amateis RL, Burkhart HE (2002) Top height definition and its effect on site index determination in thinned and unthinned loblolly pine plantations. For Ecol Manage 168:163-175

Sharma RP, Brunner A, Eid T (2012) Site index prediction from site and climate variables for Norway spruce and Scots pine in Norway. Scand J For Res 27:619-636

Skovsgaard JP, Vanclay JK (2008) Forest site productivity: a review of the evolution of dendrometric concepts for even-aged stands. Forestry 81:13-31

Smaling EMA, Janssen BH (1993) Calibration of quefts, a model predicting nutrient uptake and yields from chemical soil fertility indices. Geoderma 59:21-44

Socha J (2008) Effect of topography and geology on the site index of Picea abies in the West Carpathian, Poland. Scand J For Res 23:203-213

Socha J (2012) Long-term effect of wetland drainage on the productivity of Scots pine stands in Poland. For Ecol Manage 274:172-180

Socha J, Orzeł S (2013) Dynamiczne krzywe onitacyjne dla sosny zwyczajnej (Pinus sylvestris L.) z południowej Polski [Dynamic site index curves for Scots pine (Pinus sylvestris L.) in southern Poland]. Sylwan 157(1):26-38

StatSoft Inc. (1984-2013), n.d. STATISTICA (data analysis software system), version 10

Strub M, Cieszewski CJ (2006) Parameters of site index models. For Sci 52:182-186

Tewari VP, Kishan Kumar VS (2002) Development of top height model and site index curves for Azadirachta indica A. juss. For Ecol Manage 165:67-73

Torbert JL, Burger JA (2000) Forest land reclamation. In: Bertels J, Hatfield JL, Volenec JG, Dick WA (eds) Reclamation of drastically disturbed lands. Number 41 in the series agronomy. ASA, CSSA, SSSA, Madison, pp 371-398

Torbert JL, Burger JA, Daniels WL (1990) Pine growth variation associated with overburden rock type on a reclaimed surface mine in Virginia. J Environ Qual 19:88-92

Van Reewijk LP (2002) Procedures for soil analysis, technical Paper 9, six editio. edn. ISRIC, FAO, Wageningen

Vindušková O, Frouz J (2012) Soil carbon accumulation after open-cast coal and oil shale mining in Northern Hemisphere: a quantitative review. Environ Earth Sci 69:1685-1698

Waschkies C, Hüttl R (1999) Microbial degradation of geogenic organic C and N in mine spoils. Plant Soil 213:221-230

White H (1980) Heteroskedasticity-consistent covariance matrix estimator and a direct test for heteroskedasticity. Econometrica 48:817-838

Zipper CE, Burger J, Skousen JG, Angel PN, Barton CD, Davis V, Franklin J (2011a) Restoring forests and associated ecosystem services on appalachian coal surface mines. Environ Manage 47:751-765

Zipper CE, Burger JA, McGrath JM, Rodrigue JA, Holtzman GI (2011b) Forest restoration potentials of coal-mined lands in the eastern United States. J Environ Qual 40:1567-1577 